\title{
Response of bacterial community to simulated nitrogen deposition in soils and a unique relationship between plant species and soil bacteria in the Songnen grassland in Northeastern China
}

\author{
S. Sun ${ }^{1}$, F. Xing ${ }^{1 *}$, H. Zhao ${ }^{1,2}$, Y. Gao ${ }^{1}$, Z. Bai ${ }^{1}$, Y. Dong ${ }^{2}$ \\ ${ }^{1}$ Key Laboratory of Vegetation Ecology, Ministry of Education; Institute of Grassland Science, Northeast Normal University, \\ No. 5268, Renmin Street, Changchun, Jilin Province, 130024, P. R. China. ${ }^{2}$ Biotechnology Research Center, Jilin Academy of \\ Agricultural Sciences, Changchun, Jilin Province, 130033, P. R. China. "Corresponding authors: xingf522@126.com
}

\begin{abstract}
Nitrogen $(\mathrm{N})$ deposition greatly affects the above ground biological composition of grasslands and soil properties. However, its influence on the relationship among soil, plant and bacterial communities remain controversy. We calculated Shannon-wiener index to measure the soil bacterial diversity based on denaturing gradient gel electrophoresis, and investigate the roles of vegetation and soil properties on the soil bacterial community under $\mathrm{N}$ addition. A three-year simulated $\mathrm{N}$ deposition experiment was conducted in a forbs community dominated by Leymus chinensis (Trin.) Tzvel. and Artemisia scoparia Wald. Et. Kit. $\mathrm{N}$ was added at five levels (0, 23, 46, 69, $92 \mathrm{~kg} \mathrm{ha}^{-1} \mathrm{yr}^{-1}$ ). Our results showed that $\mathrm{N}$ addition increased the soil microbial biomass carbon (SMBC) and soil bacterial diversity. Moderate $\mathrm{N}\left(23,46,69 \mathrm{~kg} \mathrm{ha}^{-1} \mathrm{yr}^{-1}\right)$ addition increased the soil bacterial diversity, whereas excess $\mathrm{N}\left(92 \mathrm{~kg} \mathrm{ha}^{-1} \mathrm{yr}^{-1}\right)$ addition inhibited it. The SMBC and soil bacterial diversity were related to richness of plant functional groups. In particular, SMBC had positive correlation with biomass of annuals and biennials, suggesting that the effects of the plant community on the soil bacteria could be explained by a relationship between the soil bacterial community and a subset of plant species rather than all species.
\end{abstract}

Keywords: Nitrogen deposition, soil bacterial community, species richness, resource availability, Songnen grassland

\section{Introduction}

Nitrogen $(\mathrm{N})$ deposition is an important component in the global $\mathrm{N}$ cycle that has induced large impacts on the health and function of terrestrial ecosystems worldwide (Liu et al. 2011). $\mathrm{N}$ addition can alter the composition of plant communities, improve plant growth and productivity and influence the rates of nutrient cycling and retention (Ollivier et al. 2011), thus affecting the composition and diversity of soil microbial communities. Soil bacterial diversity includes genetic, functional and taxonomic diversity. Many studies have examined the effects of $\mathrm{N}$ fertilization on soil microbial biomass and the 
functional diversity of specific soil bacteria, such as the community structure of ammonia oxidizers and nitrite oxidizers (Wertz et al. 2012). In a study of successional grassland and cultivated agricultural field systems, increased $\mathrm{N}$ availability had no consistent effects on the richness and diversity of soil bacterial communities (Ramirez et al. 2010), whereas a study of forest soils showed that experimental $\mathrm{N}$ deposition altered actinobacterial community composition (Eisenlord and Zak 2010). Most grassland in northern China has suffered heavily from over-grazing since the early 1980s, resulting in severe land degradation and soil $\mathrm{N}$ deficiency (Zhang et al. 2008). However, few studies have examined the effects of $\mathrm{N}$ addition on the soil bacterial community in N-limited grassland. Heterotrophic soil bacteria influence nutrient availability by mineralizing nutrients from organic matter, whereas plants, in turn, provide organic carbon (C) that fuels bacterial growth and activity in terrestrial ecosystems (Kaye and Hart 1997). There are two hypotheses about the function of plant diversity. The redundancy hypothesis assumes that more than one species performs a given role within an ecosystem (Walker 1992), whereas the singular hypothesis states that each plant species contributes uniquely to the functioning of the belowground system (Eisenhauer et al. 2010). Plant-microbe interactions in soil are an integral component of the influence of plant diversity on ecosystem function. It is not clear which hypothesis best explains the relationship between the plant community and soil bacterial community.

Interactions among plants, soil and bacterial community regulate nutrient cycling in ecosystems and determine the spatial and temporal patterns of $\mathrm{N}$ transformations (Bohlen et al. 2001). These interactions determine the quality and quantity of resources available to microbes. Environmental conditions and plant diversity have been found to shape soil bacterial communities by altering their abundance and composition (Hossain et al. 2010). These studies investigated the influence of soil bacterial diversity and the effects of soil bacterial community structure on nutrient cycling. Nonetheless, interactions vary spatially and temporally, given the complexity and variation of ecosystems.
To identify the primary influences on the correlations among the plant community, the soil physico-chemical characteristics and the soil bacterial diversity may enhance our understanding of the potential effects of $\mathrm{N}$ deposition on grassland ecosystem.

We conducted an experiment of simulated $\mathrm{N}$ deposition on the Songnen plain, an arid and semi-arid region of Northeastern China, and also distributed in the eastern end of the Eurasian steppe zone. Over-grazing has led to heavy soil $\mathrm{N}$ deficiencies detected in 2006 . The zonal vegetation type is Leymus chinensis (Trin.) Tzvel. meadow steppe. Prior to the present study, changes in plant communities and soil characteristics had been investigated for 3 consecutive years (data has not been published). The PCR-DGGE method, used extensively in studies of grassland soils, had been conducted to document changes in the bacterial community structure, However, the analytical technique has some limitations: Only relatively small fragment size of PCR products can be separated, recovering DNA sequences information from excised gel bands ultimately requires cloning (Nakamura and Sakai 2011). Ecological research on the responses of meadow steppe to global changes is now an important component of studies of grassland vegetation. This study aimed at determining 1) whether simulated $\mathrm{N}$ deposition would alter the soil microbial community in Songnen grassland, 2) the relationship between the plant community and the soil bacterial community.

\section{Material and Methods}

\subsection{Study site, study design and soil sampling}

The study area is located in the southwestern region of the Songnen grassland at the CAS Tongyu Semiarid Climate-Environment Field Station $\left(44^{\circ} 25^{\prime} \mathrm{N}\right.$, $122^{\circ} 52^{\prime} \mathrm{E}$ ) in Jilin, China. The dominant plant is $L$. chinensis. The soils are mainly composed of sandy soil, slight chernozem, salty alkaline soil and meadow soil. This region experiences a north temperate continental 
monsoon climate. The mean annual temperature is $5.1^{\circ} \mathrm{C}$, but temperatures can range widely, from $-32^{\circ} \mathrm{C}$ to $38.9^{\circ} \mathrm{C}$. The mean annual precipitation is 404 $\mathrm{mm}$. Our study area encompasses $47.7 \mathrm{hm}^{2}$ and has been enclosed by a fence since the autumn of 2006, preventing grazing. The chosen forbs community was at an early stage of restoration succession to the climax vegetation. Important plants in the community include L. chinensis, Artemisia scoparia Wald. Et. Kit., Potentilla flagellaris Willd. ex Schlecht and Lespedeza davurica (Laxm.) Schindl.

A total of fifteen $7 \times 7 \mathrm{~m}$ plots were arranged in a randomized block design in the forbs community, all with flat topography and uniform vegetation. The plots were separated by $1 \mathrm{~m}$ buffers to avoid edge effects. The fertilizer was urea and contained $46 \% \mathrm{~N}$. The treatments were control (CK), T1 $\left(50 \mathrm{~kg} \mathrm{ha}^{-1} \mathrm{yr}\right.$ $\left.{ }^{1}\right), \mathrm{T} 2\left(100 \mathrm{~kg} \mathrm{ha}^{-1} \mathrm{yr}^{-1}\right), \mathrm{T} 3\left(150 \mathrm{~kg} \mathrm{ha}^{-1} \mathrm{yr}^{-1}\right)$ and T4 $\left(200 \mathrm{~kg} \mathrm{ha}^{-1} \mathrm{yr}^{-1}\right)$. These additions were equivalent to pure $\mathrm{N}$ addition of $0,23,46,69$ and $92 \mathrm{~kg} \mathrm{ha}^{-1} \mathrm{yr}^{-1}$, respectively. We chose this level of $\mathrm{N}$ addition because a report estimated that the community saturation of $\mathrm{N}$ deposition rates was approximately $105 \mathrm{~kg} \mathrm{ha}^{-1} \mathrm{yr}^{-1}$ in this temperate grassland ecosystem, even though the atmospheric $\mathrm{N}$ deposition in this temperate ecosystem was as high as $27 \mathrm{~kg} \mathrm{ha}^{-1} \mathrm{yr}^{-1}$ in recent ten years (Bai et al. 2010). There were 3 replicate plots for each treatment level. The plots were fertilized once a year in mid-June from 2008 to 2010.

Aboveground vegetation surveys (measuring plant community height, coverage, and plant species richness) were conducted each year in mid-August in three $1 \times 1 \mathrm{~m}$ quadrats randomly located within the central $25 \mathrm{~m}^{2}$ of each $7 \times 7 \mathrm{~m}$ plot. We classified all plant species into five functional groups based on life forms: annuals and biennials (AAB), perennial forbs $(\mathrm{PF})$, perennial rhizome grasses $(\mathrm{PR})$, shrubs and semi-shrubs (SS) and perennial bunch grasses (PB). The most abundant plant species of AAB, PF, PR, SS and PB were A. scoparia, P. flagellaris, L. chinensis, L. davurica and Cleistogenes squarrosa (Trin.) Keng, respectively. Gueldenstaedtia verna (Georgi) Boiss. was also abundant in the forbs community, belonging to the PF group.

After vegetation survey in the 2010 , soil samples were collected from the upper $15 \mathrm{~cm}$ of soil at 3 randomly selected points in each plot and combined. Then carefully removing the surface organic materials and fine roots, each mixed sample was divided into two parts. One part was air-dried for analysis of soil physicochemical properties, and the other was stored at $4{ }^{\circ} \mathrm{C}$, sifted through a $2 \mathrm{~mm}$ sieve before DNA extraction.

\subsection{Soil characteristics and the soil microbial biomass carbon}

Soil water content (SWC) was determined gravimetrically by weighing after drying in an oven at $105^{\circ} \mathrm{C}$ for $12 \mathrm{~h}$. Air-dried soil samples were used for measuring $\mathrm{pH}$, soil organic $\mathrm{C}$ (SOC) content, and soil total $\mathrm{N}$ concentration. $\mathrm{pH}$ values were measured in water suspension (water/soil=2.5:1). SOC was measured using the $\mathrm{K}_{2} \mathrm{Cr}_{2} \mathrm{O}_{7}$ titration method after digestion. Soil total $\mathrm{N}$ concentration was measured using the Kjeldahl method (Bremner 1965). Soil microbial biomass carbon (SMBC) was measured using the chloroform fumigation method using Kc $1 / 4$ 0.45 (Jenkinson 1988).

\subsection{DNA extraction and PCR-DGGE analysis of soil bacteria}

We modified the methodology of (Zhou et al. 1996) to enhance extraction of total soil DNA. Briefly, $3 \mathrm{~g}$ of a soil sample from each plot was added to $6 \mathrm{ml}$ DNA extraction solution and $600 \mu 1$ lysozyme $\left(15 \mathrm{mg}^{\circ} \mathrm{ml}^{-1)}\right.$. The samples were incubated in a water bath at $37^{\circ} \mathrm{C}$ for $2 \mathrm{~h}$, then added to $1 \mathrm{ml} \mathrm{20 \%}$ SDS and incubated in a $65^{\circ} \mathrm{C}$ water bath overnight. A $1 / 3$ volume $\mathrm{NaCl}$ was added to the samples, which were then mixed vigorously and centrifuged for $15 \mathrm{~min}(6,000 \times \mathrm{g})$. The supernatant was collected, and an equal volume of chloroform was added. Isoamyl alcohol (24:1) was used to clarify the mixture, and this step was repeated 
twice. Then, 0.6 times the volume of isopropyl alcohol was added to the supernatant for $2 \mathrm{~h}$ at room temperature.

This step was followed by centrifugation for $15 \mathrm{~min}$ $(16,000 \times \mathrm{g})$. The purified DNA was then re-suspended in $200 \mu 1 \mathrm{TE}$.

The PCR amplification was performed using the primer pair F338(5'(5'-CGCCCGCCGCGCGC GGCGGGCGGGGCGGGGGCACGGGGGGA CTCCTACGGGAGGCAGCAG-3') and R518 (5'-ATTACCGCGGCTGCTGG-3') targeting 16S rDNA (Ovreås et al. 1997). Each amplification contained 20 ng DNA, $5 \mu 110 \times$ PCR buffer, $2 \mathrm{mM}$ $\mathrm{MgCl}_{2}, 200 \mu \mathrm{M}$ of each dNTP, $20 \mathrm{pmol}$ of each primer and $2.5 \mathrm{U}$ of DNA polymerase in a final volume of 25 $\mu 1$. PCR amplification was performed using one cycle of $94^{\circ} \mathrm{C}$ for $5 \mathrm{~min}$, followed by 34 cycles of $94^{\circ} \mathrm{C}$ for $1 \mathrm{~min}, 50^{\circ} \mathrm{C}$ for $1 \mathrm{~min}$, and $72^{\circ} \mathrm{C}$ for $40 \mathrm{~s}$, with a final cycle of $72^{\circ} \mathrm{C}$ for $10 \mathrm{~min}$.

DGGE analysis was performed using a Dcode system (Bio-Rad, Hercules, CA, USA). Polyacrylamide gels were cast using 40-60\% denaturant, and electrophoresis was run overnight for $12 \mathrm{~h}$ at a constant temperature of $60^{\circ} \mathrm{C}$ at $110 \mathrm{~V}$. After electrophoresis, the gels were soaked in EB nucleic acid gel stain for $45 \mathrm{~min}$. The stained gels were photographed using a Gel Doc 2000 Molecular Imaging System (Bio-Rad, CA, USA). The band intensities of each lane were read based on peak heights in the densitometric curve, and the entire process was based on computations made using Quantity-one 4.2.3 software (Bio-Rad).

\subsection{Cloning and sequencing of DGGE fragments}

The bands excised from the DGGE gels were washed twice with $1 \mathrm{ml}$ sterilized distilled water in a $1.5 \mathrm{ml}$ tube, and a portion of the gel piece was used as the direct template for PCR to recover the DNA fragments. PCR amplification was performed using one cycle of $95^{\circ} \mathrm{C}$ for $5 \mathrm{~min}$, followed by 30 cycles of $94^{\circ} \mathrm{C}$ for 1 $\min , 50^{\circ} \mathrm{C}$ for $50 \mathrm{~s}, 72^{\circ} \mathrm{C}$ for $40 \mathrm{~s}$ and $72^{\circ} \mathrm{C}$ for 10 min. PCR products were ligated into the pMD18-T vector (TaKaRa, Dalian, China) and transformed into competent E. coli. The sequencing reactions of the selected clones were performed by Beijing Genomics Institute, and eight nucleotide sequences obtained in this study were sent to NCBI database. The accession numbers for the excised band sequence are KC244350 to $\mathrm{KC} 244357$.

\subsection{Statistical analyses}

The Shannon-Wiener index $(\mathrm{H})$ was used to measure the soil bacterial diversity and plant diversity; $\mathrm{H}$ was calculated based on the band intensity in the gel lanes as follows; $\quad H=-\sum_{i=1}^{s}\left(n_{i} / N\right)\left(\log n_{i} / N\right)$

where $n_{i}$ is the height of the peak and $\mathrm{N}$ is the sum of all peak heights of the densitometric curve (Degens et al. 2000).

A one-way ANOVA was performed to test for effects of experimental nitrogen deposition on soil and vegetation variables, including total soil $\mathrm{N}$ concentration, soil $\mathrm{pH}$, SWC, aboveground plant biomass (AB), soil bacterial diversity, SMBC, plant species richness $S R=(S-1) / \ln N$ where $S$ is the number of plant species, $N$ is the number of individual plant species), and the relative important value of the plant species $R I V=(R C+R D+R F) / 3$ where $\mathrm{RC}$ is the relative coverage, $\mathrm{RD}$ is the relative density and RF is the relative frequency). A multiple comparison analysis between each sample in the different treatments was performed using a Duncan test at the significance level $p<0.05$. A correlation analysis was used to explore the relationship between the most discriminating soil and vegetation variables with the soil microbial properties. Data that were not normally distributed were transformed prior to analysis using square-root or log transformations. Statistical tests were performed using SPSS software (SPSS Statistics 17.0.1, Chicago, USA).

A redundancy analysis (RDA), which analyzes the contribution of each environmental factor to variation in the biological community, was used to quantify and test for effects of soil and vegetation variables on the 
soil bacterial community (Monte Carlo permutation test with 999 permutations, $p<0.05$ ). The band intensity (relative surface of the peak compared to the surfaces of all the peaks in the profile) as corresponding to the relative abundance of the corresponding group. Bands with a minimum area below $1 \%$ were discarded (Kennedy et al. 2004). The entire process was subjected to detrended correspondence analysis using CANOCO Software 4.5 (Microcomputer Power, USA).

\section{Results}

\subsection{Effects of $N$ addition on soil bacterial community}

The band profiles determined by DGGE were correlated with the soil bacterial diversity with added N (Figure 1). According to the number and intensity of the bands in each lane, the change in the soil bacterial diversity was visually observed along the gradient of $\mathrm{N}$ addition. Across all treatments, the number of bands detected by DGGE was higher in the T3 treatment than in the others. After DGGE analysis, the brightest bands (Z1-Z8) were excised and sequenced because of their consistency and specificity (Figure 1). We obtained similar sequences from Bacterium, Bacillus subtilis, uncultured Proteobactium and Bradyrhizobium sp. from GenBank. These sequences clustered within the proteobacterium and Firmicutes. DGGE images were analyzed to determine the number and peak density of the bands in each lane, and the Shannon-Wiener index of the sample was then calculated (Table 1). Regrettably, the separated fragment sizes of PCR products were relative small due to the limitation of analytical technique. Hence, further study should consider utilize the high-throughput sequencing, so that we can obtain better understanding of the microbial diversity.

\subsection{Variation in soil, vegetation and soil bacterial characteristics}

A one-way ANOVA showed that the soil $\mathrm{pH}$ was significantly lower $(\mathrm{F} 4,1=10.81, p<0.05)$ in the $\mathrm{T} 4$ treatment than in the other treatments (Table 1), whereas the total soil $\mathrm{N}$ concentration and the SWC were unaffected by $\mathrm{N}$ addition (Table 1). $\mathrm{N}$ addition significantly reduced plant species richness (SR) $\left(\mathrm{F}_{4,10}=8.65, p<0.05\right.$; Table 1) but significantly increased plant aboveground biomass $(\mathrm{AB})\left(\mathrm{F}_{4,10}=1.803, p<0.05\right.$; Table 1). The list of plant species within each plots were given in Table S1. Following N addition, soil bacterial diversity increased along a gradient between the $\mathrm{T} 1$ and $\mathrm{T} 3$ treatments and was significantly higher in the treatment groups than in the CK, although levels decreased in the T4 treatment. In addition, relative to the $\mathrm{CK}$, the SMBC increased significantly from the $\mathrm{T} 1$ to the $\mathrm{T} 4$ treatment after $\mathrm{N}$ addition $\left(\mathrm{F}_{4,10}=3.335\right.$, $p<0.05$; Table 1).

\subsection{Correlations between bacterial, soil and vegetation characteristics}

The correlation analysis (Table S2) showed that the soil bacterial diversity was significantly and positively correlated with plant community coverage (PC) $(r=0.613, \mathrm{p}<0.05)$ and height $(\mathrm{PH})(r=0.711, p<0.01)$, and the SMBC was significantly and positively correlated with aboveground biomass $(r=0.792$, $p<0.01)$ and $\mathrm{PC}(r=0.585, p<0.05)$. In contrast, both the soil bacterial Shannon-Wiener index and the SMBC were negatively correlated with plant species richness ( $r=-0.714, p<0.01 ; r=-0.656, p<0.01$, respectively). Moreover, the soil bacterial Shannon-Wiener index was negatively correlated with the $\mathrm{C} / \mathrm{N}$ ratio $(r=-$ $0.632, p<0.05)$.

The RDA of the soil bacteria, soil, and vegetation data was performed to quantify the effects of environmental factors on the relative abundance of soil bacteria (Figure 2). Eigenvalues for the first, second, third and fourth axes were $0.517,0.196,0.085$ and 0.060 , respectively. Longer arrows indicate stronger relationships. The arrows for $\mathrm{PC}, \mathrm{AB}$ and $\mathrm{SWC}$ were longer than for other variables, indicating that these factors play important roles in the soil bacterial community. The relative abundance of bacteria in the $\mathrm{CK}$ and $\mathrm{T} 1$ treatments showed a negative relationship with $\mathrm{PD}, \mathrm{SR}, \mathrm{pH}$ and 
the $\mathrm{C} / \mathrm{N}$ ratio, and had a negative relationship with $\mathrm{pH}$ in $\mathrm{T} 2$ and $\mathrm{T} 3$ treatments. However, the relative abundance of bacteria in the $\mathrm{T} 2$ and $\mathrm{T} 3$ treatments were positively influenced by SWC, $\mathrm{AB}$ and $\mathrm{PC}$. Moreover, in $\mathrm{T} 4$ treatment, the relative abundance of bacteria was positively influenced by $\mathrm{AB}, \mathrm{PC}, \mathrm{N}$, $\mathrm{SOC}$, available potassium (AK) and $\mathrm{pH}$. The soil and vegetation variables together explained $55.7 \%$ variance in the composition of soil bacteria (Monte Carlo permutation test with 999 permutations, $p<0.05$ ).

\subsection{Effects of individual plant species on the soil} bacterial community

$\mathrm{N}$ addition had no significant effects on the aboveground biomass of L. chinensis, A. scoparia, $P$. flagellaris or L. davurica, which were the dominant species and the most common accompanying species. However, $\mathrm{N}$ addition significantly decreased the aboveground biomass of G. verna (Figure 3). Relative to the CK group, the aboveground biomasses of $L$. chinensis and A. scoparia were higher in the treatment groups, although not significantly so. The correlation analysis (Table 2) showed that the soil bacterial Shannon-Wiener index was significantly and positively correlated with the relative important value of $L$. davurica $(r=0.724, p<0.01)$ and significantly and negatively correlated with the aboveground biomass of $G$. verna $(r=-0.664, p<0.01)$. Moreover, SMBC increased linearly with the aboveground biomass of A. scoparia $(r=0.641, p<0.01)$ and was negatively correlated with the aboveground biomass of $G$. verna $(r=-0.523, p<0.05)$.

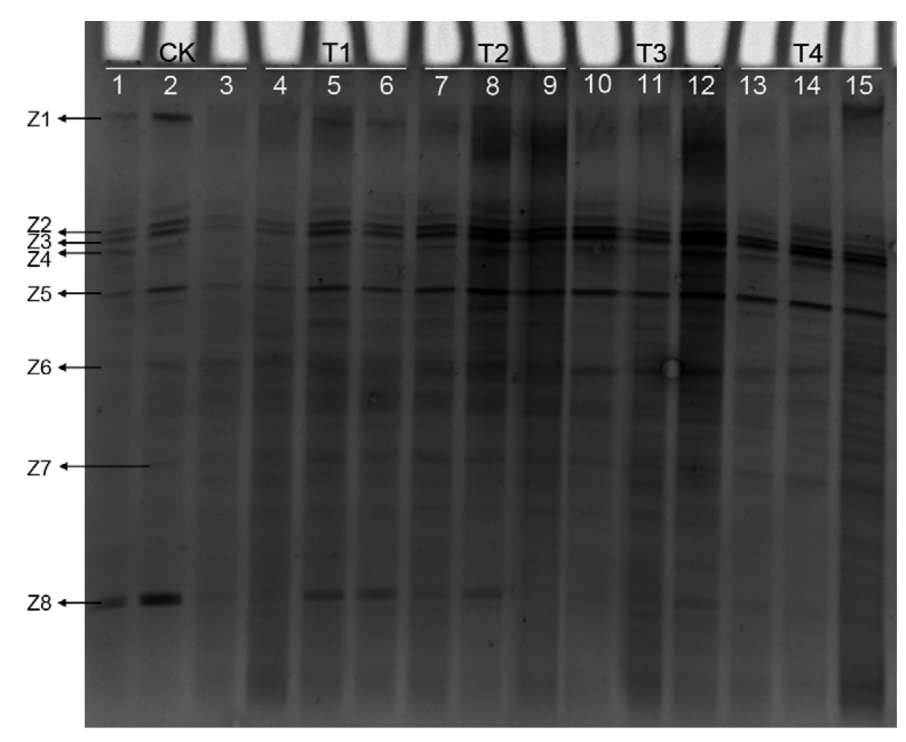

Figure 1. PCR-DGGE analysis of bacterial diversity following $\mathrm{N}$ addition to soils in the Songnen grassland. The numbering is as follows: 1-3, CK; 4-6, T1; 7-9, T2; 10-12, T3; and 13-15, T4. The treatments were control (CK), T1 $\left(23 \mathrm{~kg} \mathrm{ha}^{-1} \mathrm{yr}^{-1}\right)$, T2 $\left(46 \mathrm{~kg} \mathrm{ha}^{-1} \mathrm{yr}^{-1}\right), \mathrm{T} 3\left(69 \mathrm{~kg} \mathrm{ha}^{-1} \mathrm{yr}^{-1}\right)$ and T4 $\left(92 \mathrm{~kg} \mathrm{ha}^{-1} \mathrm{yr}^{-1}\right)$. We selected eight bands for sequencing (Z1-Z8). We calculated the soil bacterial Shannon-Wiener index from the gel image according to the number and peak heights of each band using Quantity-One software. 
Table 1. Effects of $\mathrm{N}$ addition on soil total $\mathrm{N}$ concentration (Total $\mathrm{N}$ ), soil $\mathrm{pH}$, soil water content (SWC), plant species richness (SR), aboveground plant biomass $(\mathrm{AB})$, the soil bacteria diversity $(\mathrm{H})$ and the soil microbial biomass carbon $(\mathrm{SMBC})$ in a forbs community in the Songnen grassland. Different letters within a column indicate a significant difference of the mean values $\pm \mathrm{SE}(p<0.05)$ in each plot.

\begin{tabular}{cccccccc}
\hline & \multicolumn{3}{c}{ Soil } & \multicolumn{2}{c}{ Vegetation } & \multicolumn{2}{c}{ Soil bacteria } \\
\cline { 2 - 8 } & Total N $(\mathrm{g} / \mathrm{kg})$ & $\mathrm{pH}$ & SWC $(\%)$ & SR & AB $\left(\mathrm{g} / \mathrm{m}^{2}\right)$ & $H$ & SMBC $(\mathrm{Mg} * \mathrm{C} / \mathrm{g})$ \\
\hline CK & $1.4 \pm 0.02 \mathrm{a}$ & $7.78 \pm 0.04 \mathrm{~b}$ & $6.89 \pm 0.55 \mathrm{a}$ & $1.69 \pm 0.03 \mathrm{~b}$ & $319.15 \pm 46.60 \mathrm{a}$ & $2.14 \pm 0.19 \mathrm{a}$ & $108.15 \pm 9.74 \mathrm{a}$ \\
T1 & $1.5 \pm 0.02 \mathrm{a}$ & $7.77 \pm 0.02 \mathrm{~b}$ & $6.16 \pm 0.47 \mathrm{a}$ & $1.57 \pm 0.12 \mathrm{~b}$ & $330.00 \pm 43.16 \mathrm{ab}$ & $2.70 \pm 0.07 \mathrm{~b}$ & $137.89 \pm 11.60 \mathrm{a}$ \\
T2 & $1.4 \pm 0.04 \mathrm{a}$ & $7.88 \pm 0.01 \mathrm{c}$ & $7.37 \pm 0.60 \mathrm{a}$ & $0.98 \pm 0.16 \mathrm{a}$ & $359.06 \pm 15.04 \mathrm{~b}$ & $2.92 \pm 0.18 \mathrm{~b}$ & $202.77 \pm 21.46 \mathrm{ab}$ \\
T3 & $1.5 \pm 0.01 \mathrm{a}$ & $7.70 \pm 0.01 \mathrm{~b}$ & $7.16 \pm 0.71 \mathrm{a}$ & $0.81 \pm 0.15 \mathrm{a}$ & $432.97 \pm 53.70 \mathrm{c}$ & $3.12 \pm 0.13 \mathrm{c}$ & $254.14 \pm 21.26 \mathrm{ab}$ \\
T4 & $1.5 \pm 0.05 \mathrm{a}$ & $7.59 \pm 0.05 \mathrm{a}$ & $6.69 \pm 0.69 \mathrm{a}$ & $0.72 \pm 0.21 \mathrm{a}$ & $458.10 \pm 60.28 \mathrm{~d}$ & $2.99 \pm 0.07 \mathrm{~b}$ & $310.92 \pm 18.16 \mathrm{~b}$ \\
\hline
\end{tabular}

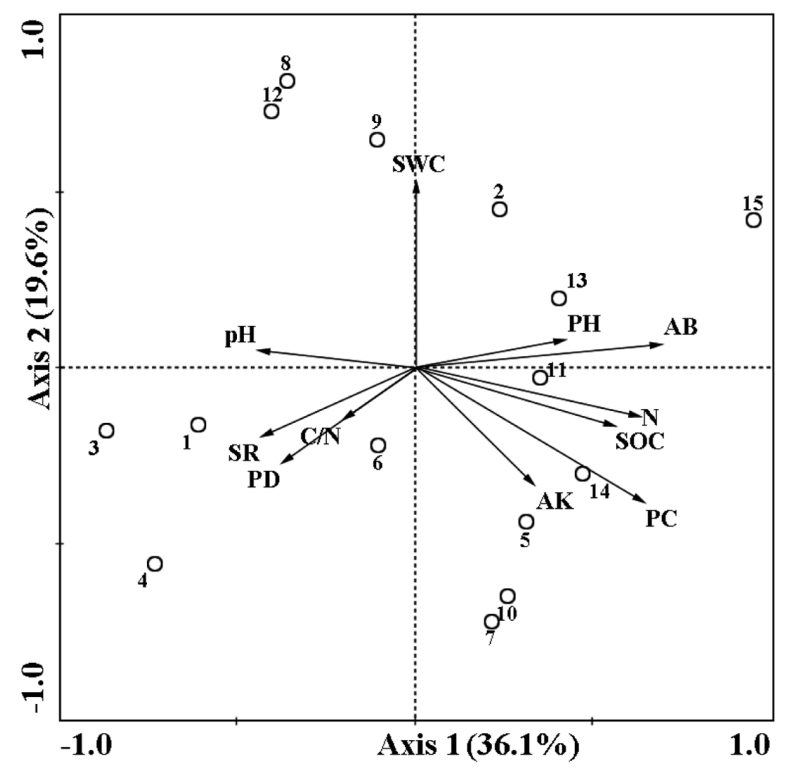

Figure 2. Bioplot diagram of the redundancy analysis of the relative abundance of soil bacteria as a function of soil and vegetation variables under $\mathrm{N}$ deposition in the Songnen grassland. Soil total nitrogen concentration $(\mathrm{N})$, soil organic carbon (SOC), soil water content $(\mathrm{SWC})$, soil $\mathrm{pH}(\mathrm{pH})$, soil $\mathrm{C} / \mathrm{N}$ ratio $(\mathrm{C} / \mathrm{N})$, available potassium $(\mathrm{AK})$, plant community height $(\mathrm{PH})$, aboveground plant biomass (AB), plant community coverage (PC), plant species richness (SR) and plant diversity (PD) were used as quantitative explanatory variables. Axis 1 and Axis 2 together explained $55.7 \%$ of the total variance $(p<0.05)$. The numbering of $1-15$ is as follows: $1-3, \mathrm{CK} ; 4-6, \mathrm{~T} 1 ; 7-9, \mathrm{~T} 2$; 10-12, T3; and 13-15, T4. 

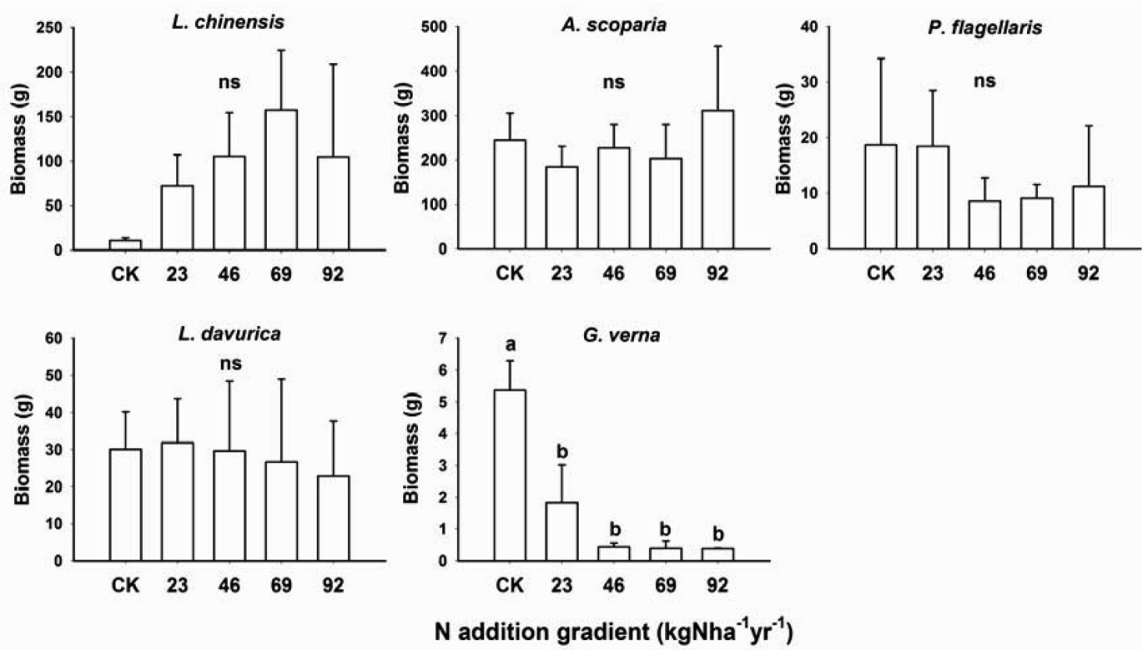

Figure 3. Effects of nitrogen addition on the aboveground biomass of five plant species (Mean $\pm \mathrm{SE}$ ). Different letters above bars indicate significant differences $(p<0.05)$ among treatments, $n s=$ no significance.

Table 2. Correlations between the soil bacteria diversity $(\mathrm{H})$ or soil microbial biomass carbon (SMBC) and the aboveground biomass or relative importance value (RIV) of the five plant species.

\begin{tabular}{|c|c|c|c|c|c|c|c|c|c|c|}
\hline & \multicolumn{2}{|c|}{ L. chinensis } & \multicolumn{2}{|c|}{ A. scoparia } & \multicolumn{2}{|c|}{ P. flagellaris } & \multicolumn{2}{|c|}{ L. davurica } & \multicolumn{2}{|c|}{ G. verna } \\
\hline & Biomass & RIV & Biomass & RIV & Biomass & RIV & Biomass & RIV & Biomass & RIV \\
\hline$H$ & -0.075 & -0.244 & 0.473 & 0.429 & -0.221 & -0.092 & 0.120 & $0.724 * *$ & $-0.664 * *$ & 0.505 \\
\hline SMBC & -0.090 & -0.142 & $0.641 * *$ & 0.441 & -0.293 & -0.104 & 0.316 & 0.465 & $-0.523^{*}$ & 0.340 \\
\hline
\end{tabular}

Symbols * and ${ }^{* *}$ indicate the significance of the Pearson correlation at $p<0.05$ and $p<0.01$, respectively.

\subsection{Effects of plant functional groups on the soil} bacterial community

None of the plant functional groups changed significantly along the $\mathrm{N}$ addition gradient (Figure 4). Nonetheless, the aboveground biomass of PR was higher in the treatment groups than in the $\mathrm{CK}$, whereas the aboveground biomasses of AAB (except
T4), PF, SS and PB were lower in the treatment groups than in the $\mathrm{CK}$. Both the soil bacterial Shannon-Wiener index and SMBC were negatively correlated with the richness of PF, PR and SS (Table 3). In addition, a significant positive correlation between SMBC and aboveground biomass of the AAB was observed $(r=0.683, p<0.01)$. 

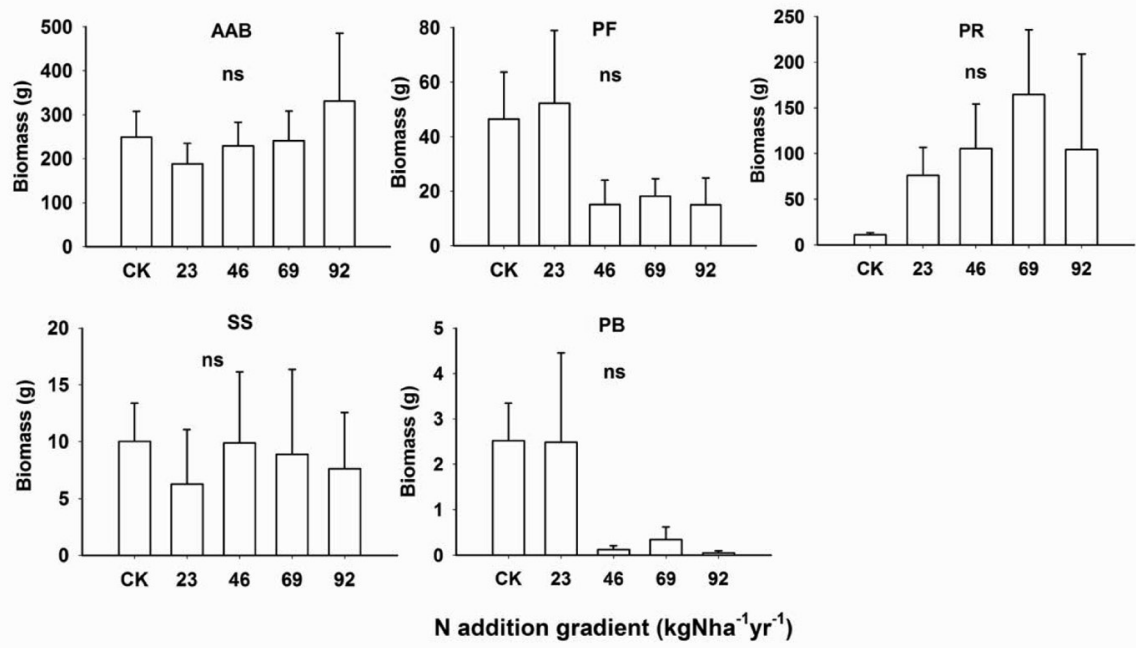

Figure 4. Effects of nitrogen addition on the aboveground biomass of plant functional groups in the forbs community $($ Mean $\pm \mathrm{SE})$. Different letters above bars indicate significant differences $(p<0.05)$ among treatments, ns $=$ no significance. (Abbreviations of plant functional groups: $\mathrm{AAB}=$ annuals and biennials, $\mathrm{PF}=$ perennial forbs, $\mathrm{PR}=$ perennial rhizome grasses, $\mathrm{SS}=$ shrubs and semi-shrubs, $\mathrm{PB}=$ perennial bunch grasses).

Table 3. Correlations between the soil bacteria diversity $(\mathrm{H})$ or soil microbial biomass carbon (SMBC) and the aboveground biomass or richness (FR) of the five plant functional groups.

\begin{tabular}{|c|c|c|c|c|c|c|c|c|c|c|}
\hline & \multicolumn{2}{|c|}{$\mathrm{AAB}$} & \multicolumn{2}{|c|}{$\mathrm{PF}$} & \multicolumn{2}{|c|}{ PR } & \multicolumn{2}{|c|}{ SS } & \multicolumn{2}{|c|}{$\mathrm{PB}$} \\
\hline & Biomass & FR & Biomass & FR & Biomass & FR & Biomass & FR & Biomass & FR \\
\hline$H$ & 0.507 & -0.216 & -0.429 & $-0.711 * *$ & -0.081 & $-0.698 * *$ & -0.496 & $-0.645^{* *}$ & 0.183 & -0.117 \\
\hline SMBC & $0.683 * *$ & -0.127 & -0.473 & $-0.737 * *$ & -0.092 & $-0.768 * *$ & -0.447 & $-0.562 *$ & 0.433 & -0.268 \\
\hline
\end{tabular}

Symbols * and ** indicate the significance of the Pearson correlation at $p<0.05$ and $p<0.01$, respectively. (Abbreviations of plant functional groups: $\mathrm{AAB}=$ annuals and biennials, $\mathrm{PF}=$ perennial forbs, $\mathrm{PR}=$ perennial rhizome grasses, $\mathrm{SS}=$ shrubs and semishrubs, $\mathrm{PB}=$ perennial bunch grasses). 


\section{Discussion}

\subsection{Effects of $N$ addition on the soil bacterial community}

$\mathrm{N}$ addition increased the soil bacterial diversity (Figure 1; Table 1), though a study had found lower bacterial diversity and a significant changes in microbial community structure in long-term fertilized plots (Campbell et al. 2010). This finding is consistent with the increase in the diversity of soil bacterial functional groups following different $\mathrm{N}$ fertilization $(0,100,150$ and $250 \mathrm{~kg}$ urea-N ha ${ }^{-1}$, respectively) (Xu et al. 2012). Although the Songnen grassland is an N-limited ecosystem, these results suggest that soil conditions may have little direct effect on bacterial community composition and that the stability of the soil bacterial phyla may be related to other factors, such as plant community composition. Plants release secondary compounds into the soil environment from their roots as exudates, since soil microbial communities depend on plant root exudates for carbon and nitrogen sources, this shift in vegetation is thought to influence soil microbial community structure (Sanon et al. 2009). In our study site, the dominant species Leymus chinensis and Artemisia scoparia might provide constituents of root exudates to soil and are metabolized by a wide variety of bacteria. Therefore, some plant species may have important indirect effects on the soil bacteria phyla.

\subsection{Effects of soil characteristics on the soil bacterial community}

The distribution of nutrients and soil nutrient availability affect the biomass, activity and composition of soil bacterial communities (Ramirez et al. 2010). We found the soil $\mathrm{C} / \mathrm{N}$ ratio to be an important factor affecting the soil bacterial diversity (Table S2). That is, the soil $\mathrm{C} / \mathrm{N}$ ratio may affect the soil bacterial diversity through its effects on resource availability in soils and the plant community composition. The SWC was also strongly related to the soil bacterial diversity in our study (Figure 2). SWC regulates bacterial activity and diversity, and in arid and semiarid ecosystems, it is an important factor limiting plant growth. The influence of SWC on the soil bacterial community can be explained by the greater above- and below-ground plant productivity resulting from soil water availability (Bai et al. 2008).

Previous study observed differences among ecosystems in the diversity and richness of soil bacterial communities could largely be explained by soil $\mathrm{pH}$ (Fierer and Jackson 2006). However, our results are not consistent with those of previous studies. Although both soil $\mathrm{pH}$ and the soil bacterial diversity were lowest in the T4 treatment, there were no significant correlations. Therefore, soil $\mathrm{pH}$ might not be the critical factor in regulating the soil bacterial diversity.

The SMBC has been shown to be a reliable index of soil fertility. SMBC increased linearly with aboveground plant biomass suggests that the plants obtained sufficient nutrients to increase their biomass and contribute more root exudates to soil, such that the nutrient availability of the soils changed the soil bacterial communities (Hartmann et al. 2008); i.e., there exists a twoway interaction between the plant and soil bacterial communities in nutrient cycling.

\subsection{Effects of plant diversity on the soil bacterial community}

Previous study showed that changes in plant diversity and composition in grassland ecosystems lead to a rapid response of bacterial diversity (Loranger-Merciris et al. 2006). A study in three semi-natural Irish grasslands investigated the influence of different plant species, fertilization and $L$. perenne ingression on microbial community in soils, the results indicated that the diversity of plant communities may affect soil bacterial communities through variation in nutrient availability over time (Liliensiek et al. 2011).

With an increase in $\mathrm{N}$ availability, the growth of legumes in an ecosystem is usually replaced by the growth of non-legumes, which are normally N-limited. Accordingly, the aboveground biomass of G. verna significantly decreased with increasing $\mathrm{N}$ application (Figure 3). Nonetheless, the diversity and biomass 
of the soil bacterial community increased in response to $\mathrm{N}$ addition. In addition, the relative importance value of $L$. davurica, a main accompanying species, increased, enhancing the soil bacterial diversity (Table 2). Although $\mathrm{N}$ addition can reduce plant diversity, the dominant and main accompanying species not only persisted but increased community height, coverage, and, in particular, biomass (Figure 3, Table S1). A significant and positive correlation has found between the aboveground biomass of A. scoparia and the SMBC (Table 2), suggesting that the greater biomass of dominant plant species increased the availability of $\mathrm{C}$ and $\mathrm{N}$ to the soil microbial community, resulting in a higher SMBC. Thus, increases in the relative importance values and aboveground biomasses of the dominant and main accompanying plant species likely enhance the SMBC and change the soil bacterial diversity.

$\mathrm{N}$ addition enhanced the aboveground biomass of the PR and AAB groups (especially L. chinensis and A. scoparia) (Figure 3, Figure 4). Some keystone species can have effects on community or ecosystem function that are large relative to their total biomass, thereby increasing the amount of mineralization nutrients to below-ground communities. Most soil bacterial communities were established in the presence of a few dominant plant species or special plant functional groups (Vessey 2003), not among plant species declining or disappearing due to longterm $\mathrm{N}$ addition. Accordingly, the functional plant group $\mathrm{AAB}$ exerted significant effects on the soil bacterial community (Table 3 ). In most ecosystems, bacterial growth is limited by plant biomass production. In contrast, the $\mathrm{C}$ and $\mathrm{N}$ resources needed for the metabolism of the soil bacterial community come primarily from plant exudates or decomposing plant litter (Loranger-Merciris et al. 2006). Although a decrease in plant diversity was detected, some functional plant groups (e.g., AAB, $\mathrm{PR}$ ) provided more resources to the soil bacterial community. From the above evidence, we suggested that a unique relationship between plant species and soil bacteria. The soil bacterial community structure may depend, not on all the plant species present, but on a minority of species that have disproportionately large contributions to the plant community biomass. This hypothesis is consistent with the view that each plant species contributes to below-ground system functioning. The relationship between plant species and the soil bacterial community may have a one-tomany mechanism, with "one" designating one or a few particular plant species.

\subsection{The primary influences on the correlations among plant community, soil properties and bacterial community}

$\mathrm{N}$ availability has been shown to regulate the rate and course of plant community redevelopment in $\mathrm{N}$ gradient experiments (Tilman 1987). $\mathrm{N}$ deposition could reduce the plant species richness. Reduced competition for $\mathrm{N}$ within plant communities and changes in plant species richness may be expected to modify the nutrient availability to soil microbial communities and thus alter the soil bacterial diversity.

Although variation in the soil bacterial community is ultimately a function of resource availability in the soil (McCrackin et al. 2008), N addition directly affects plant composition and diversity. In our study, when plant community height, coverage, biomass or diversity changed, the soil bacterial diversity changed. Relative to variations in soil nutrient levels, the soil bacterial community is sensitive to vegetation characteristics (Table S2, Figure 2). Although N addition alters the soil bacterial community, the indirect effects of plant community on the soil bacterial community exceed the direct effects of soil nutrient levels. Nevertheless, many factors correlated to the 16S rRNA gene bacterial profiling detected by DGGE. The soil and vegetation factors we selected explained $55.7 \%$ of the variance in speciesenvironment relationships (Figure 2); the remaining variance cannot be explained by these factors, it is due to unmeasured environmental factors, such as soil temperature. 
Table S1. List of plant species within the quadrats $(1 \mathrm{~m} \times 1 \mathrm{~m})$.

\begin{tabular}{lll}
\hline Functional group & Latin name & Relative Biomass (\%) \\
\hline Annuals and biennials & Artemisia scoparia & 61.699 \\
& Chenopodium serotinum & 0.084 \\
& Chroris virgata & 0.024 \\
& Eragrostis pilosa & 0.018 \\
& Euphorbia humifusa & 0.014 \\
& Kochia sieversiana & $<0.001$ \\
& Kummerowia striata & 0.391 \\
& Orobanche coerulescens & 0.216 \\
& Plantago depressa & $<0.001$ \\
& Salsola collina & 1.838 \\
& Setaria viridis & 0.343 \\
& Tribulus terrester & 0.032 \\
& Astragalus adsurgens & 1.115 \\
& Astragalus melilotoides & 0.719 \\
& Astragalus scaberrimus & 0.023 \\
& Carex duriuscula & 0.262 \\
& Convolvulus ammannii & 0.192 \\
& Erodium stephanianum & 1.096 \\
& Gueldenstaedtia verna & 0.202 \\
& Inula japonica & 0.067 \\
& Ixeris denticulata & $<0.001$ \\
& Melissitus ruthenica & $<0.001$ \\
& Potentilla flagellaris & 4.079 \\
& Saussurea amara & 0.053 \\
& Taraxacum ohwianum & 0.082 \\
Perennial forbs & Vicia amoena & 0.278 \\
Perennial bunch grasses & 0.894 \\
Shrubs and semi-shrubs & Hierochloe glabra & 23.215 \\
& Leymus chinensis & 0.445 \\
& Cleistogenes squarrosa & 1.987 \\
& Lespedeza davurica & 0.617 \\
\hline
\end{tabular}


Table S2. Correlation analysis predicting the soil bacteria diversity $(H)$ and the soil microbial biomass carbon (SMBC) as a function of select vegetation and soil variables under $\mathrm{N}$ deposition in the Songnen grassland. (AB, aboveground biomass; PC, plant community coverage; SR, plant species richness; PH, plant community height; PD, plant ShannonWiener index; Total N, soil total nitrogen concentration; SOC, soil organic carbon; SWC, soil water content; C/N, soil $\mathrm{C} / \mathrm{N}$ ratio; $\mathrm{AK}$, available kalium).

\begin{tabular}{|c|c|c|c|}
\hline Dependent variables & Variables & Correlation coefficient $r$ & $R^{2}$ \\
\hline \multirow{11}{*}{$H$} & Total N & 0.262 & 0.069 \\
\hline & SOC & 0.094 & 0.009 \\
\hline & Soil pH & -0.272 & 0.074 \\
\hline & SWC & 0.270 & 0.073 \\
\hline & $\mathrm{C} / \mathrm{N}$ ratio & $-0.632^{*}$ & 0.400 \\
\hline & $\mathrm{AK}$ & 0.134 & 0.018 \\
\hline & $\mathrm{AB}$ & 0.407 & 0.165 \\
\hline & $\mathrm{PC}$ & $0.613^{*}$ & 0.376 \\
\hline & SR & $-0.714^{* i k}$ & 0.510 \\
\hline & PH & $0.711^{\text {** }}$ & 0.506 \\
\hline & $\mathrm{PD}$ & -0.395 & 0.156 \\
\hline \multirow{11}{*}{ SMBC } & Total N & 0.485 & 0.235 \\
\hline & SOC & 0.388 & 0.151 \\
\hline & Soil pH & -0.503 & 0.253 \\
\hline & SWC & 0.081 & 0.007 \\
\hline & $\mathrm{C} / \mathrm{N}$ ratio & -0.296 & 0.088 \\
\hline & $\mathrm{AK}$ & 0.282 & 0.079 \\
\hline & $\mathrm{AB}$ & $0.792^{* *}$ & 0.627 \\
\hline & $\mathrm{PC}$ & $0.585^{*}$ & 0.342 \\
\hline & SR & $-0.656^{* *}$ & 0.430 \\
\hline & $\mathrm{PH}$ & 0.488 & 0.239 \\
\hline & PD & -0.45 & 0.203 \\
\hline
\end{tabular}




\section{Conclusions}

This study aimed at identifying the primary influences on the relationship among the plant community, the soil properties and the soil bacterial community under simulated nitrogen deposition. The SMBC and soil bacterial diversity was more sensitive to plant community composition than to soil properties under the context of increased $\mathrm{N}$ addition. The increased aboveground biomass of dominant plant species and plant functional groups resulted in the increased diversity of soil bacteria and SMBC. It implied that there was a unique relationship between the soil bacterial community and a subset of plant species rather than all species.

\section{Acknowledgments}

This study was financially supported by the Open Project of the Key Laboratory of Regional ClimateEnvironment Research for Temperate East Asia (RCE-TEA), the Chinese Academy of Sciences, the Natural Science Foundation of China (31270514, 31370528 ) and the Fundamental Research Funds for the Central Universities (10SSXT148, 12SSXT154). We are grateful to Mr. J.C. Zhao of the CAS Tongyu Semi-arid Climate-Environment Field Station, who provided convenient conditions for the fieldwork; S.Z. Jia, J. Cui, W. Liu, Y. Zhang, X.L. Zhou, R.J. Bian and J. Ge assisted with field surveys.

\section{References}

Bai, Y., Wu, J., Xing, Q., Pan, Q., Huang, J., Yang, D., Han, X. 2008. Primary production and rain use efficiency across a precipitation gradient on the Mongolia plateau. Ecology. 89, 2140-2153.

Bai, Y., Wu, J., Clark, C.M., Naeem, S., Pan, Q., Huang, J., Zhang, L., Han, X. 2010. Tradeoffs and thresholds in the effects of nitrogen addition on biodiversity and ecosystem functioning: evidence from inner Mongolia Grasslands. Global Change Biol. 16, 358-372.

Bohlen, P.J., Groffman, P.M., Driscoll, C.T., Fahey, T.J., Siccama, T.G. 2001. Plant-soil-microbial interactions in a northern hardwood forest. Ecology. 82, 965-978.

Bremner, J.M. 1965. Nitrogen availability indexes. In: Norman AG (eds.). Methods of Soil Analysis. Part 2. Chemical and Microbiological Properties. American Society of Agronomy, pp. 1324-1345.

Campbell, B.J., Polson, S.W., Hanson, T.E., Mack, M.C., Schuur, E.A.G. 2010. The effect of nutrient deposition on bacterial communities in Arctic tundra soil. Environ. Microbiol. 12, 1842-1854.

Degens, B.P., Schipper, L.A., Sparling, G.P., VojvodicVukovic, M. 2000. Decreases in organic C reserves in soils can reduce the catabolic diversity of soil microbial communities. Soil Biol. Biochem. 32, 189-196.

Eisenhauer, N., Beßler, H., Engels, C., Gleixner, G., Habekost, M., Milcu, A., Partsch, S., Sabais, A.C.W., Scherber, C., Steinbeiss, S., Weigelt, A., Weisser, W.W., Scheu, S. 2010. Plant diversity effects on soil microorganisms support the singular hypothesis. Ecology. 91, 485-496.

Eisenlord, S.D., Zak, D.R. 2010. Simulated atmospheric nitrogen deposition alters actinobacterial community composition in forest soils. Soil Sci. Soc. Am. J. 74, 1157-1166.

Fierer, N., Jackson, R.B. 2006. The diversity and biogeography of soil bacterial communities. P. Natl. Acad. Sci. U.S.A. 103, 626-631.

Hartmann, A., Schmid, M., Tuinen, D.V., Berg, G. 2008. Plant-driven selection of microbes. Plant Soil. 321, 235-257. 
Hossain, M.Z., Okubo, A., Sugiyama, S. 2010. Effects of grassland species on decomposition of litter and soil microbial communities. Ecol. Res. $25,255-261$.

Jenkinson, D.S. 1988. The determination of microbial biomass carbon and nitrogen in soil. C.A.B. International, Wallingford.

Kaye, J.P., Hart, S.C. 1997. Competition for nitrogen between plants and soil microorganisms. Trends Ecol. Evol. 12, 139-143.

Kennedy, N., Brodie, E., Connolly, J., Clipson, N. 2004. Impact of lime, nitrogen and plant species on bacterial community structure in grassland microcosms. Environ. Microbiol. 6, 1070-1080.

Liliensiek, A.K., Thakuria, D., Clipson, N. 2011. Influences of plant species composition, fertilisation and lolium perenne ingression on soil microbial community structure in three Irish grasslands. Microb. Ecol. 63, 509-521.

Liu, X., Duan, L., Mo, J., Du, E., Shen, J., Lu, X., Zhang, Y., Zhou, X., He, C., Zhang, F. 2011. Nitrogen deposition and its ecological impact in China: An overview. Environ. Pollut. 159, 22512264.

Loranger-Merciris, G., Barthes, L., Gastine, A., Leadley, P. 2006. Rapid effects of plant species diversity and identity on soil microbial communities in experimental grassland ecosystems. Soil Biol. Biochem. 38, 2336-2343.

McCrackin, M.L., Harms, T.K., Grimm, N.B., Hall, S.J., Kaye, J.P. 2008. Responses of soil microorganisms to resource availability in urban, desert soils. Biogeochemistry. 87, 143-155.

Nakamura, K., Sakai, K. 2011. Denaturing gradient gel electrophoresis analysis of gut bacterial community for the Japanese earthworms. Soil Sci. Plant Nutr. 57, 519-528.
Ollivier, J., Töwe, S., Bannert, A., Hai, B., Kastl, E.M., Meyer, A., Su, M.X., Kleineidam, K., Schloter, M. 2011. Nitrogen turnover in soil and global change. FEMS Microbiol. Ecol. 78, 3-16.

Ovreås, L., Forney, L., Daae, F.L., Torsvik, V. 1997. Distribution of bacterioplankton in meromictic lake sælenvannet, as determined by denaturing gradient gel electrophoresis of PCR-amplified gene fragments coding for 16S rRNA. Appl. Environ. Microb. 63, 33-67.

Ramirez, K.S., Lauber, C.L., Knight, R, Bradford, M.A., Fierer, N. 2010. Consistent effects of nitrogen fertilization on soil bacterial communities in contrasting systems. Ecology. 91, 3463-3470.

Sanon, A., Andrianjaka, Z.N., Prin, Y., Bally, R., Thioulouse, J., Comte, G., Duponnois, R. 2009. Rhizosphere microbiota interfers with plant-plant interactions. Plant Soil. 321, 259-278.

Tilman, D. 1987. Secondary succession and the pattern of plant dominance along experimental nitrogen gradients. Ecol. Monogr. 57, 189-214.

Vessey, J.K. 2003. Plant growth promoting rhizobacteria as biofertilizers. Plant Soil. 255, 571-586.

Walker, B.H. 1992. Biodiversity and ecological redundancy. Conserv. Biol. 6, 18-23.

Wertz, S., Leigh, A.K.K., Grayston, S.J. 2012. Effects of long-term fertilization of forest soils on potential nitrification and on the abundance and community structure of ammonia oxidizers and nitrite oxidizers. FEMS Microbiol. Ecol. 79, 142-154.

Xu, Y., Yu, W., Ma, Q., Zhou, H. 2012. Responses of bacterial and archaeal ammonia oxidisers of an acidic luvisols soil to different nitrogen fertilization rates after 9 years. Biol. Fert. Soils. 48, 827-837. 
Zhang, N., Wan, S., Li, L., Bi, J., Zhao, M., Ma, K. 2008. Impacts of urea $\mathrm{N}$ addition on soil microbial community in a semi-arid temperate steppe in northern China. Plant Soil. 311, 19-28.
Zhou, J., Bruns, M.A., Tiedje, J.M. 1996. DNA recovery from soils of diverse composition. Appl. Environ. Microb. 62, 316-322. 